\title{
Special issue: improving irrigation management across the Ogallala aquifer, USA
}

\author{
Allan A. Andales ${ }^{1,3}$. Daran Rudnick² · José L. Chávez ${ }^{3}$ \\ Published online: 22 October 2020 \\ c) Springer-Verlag GmbH Germany, part of Springer Nature 2020
}

\section{Introduction}

Groundwater stored in aquifers is a major source of irrigation water for many agricultural regions that receive insufficient precipitation for crop production. In the U.S.A., the High Plains aquifer (HPA) that underlies parts of Colorado, Kansas, Nebraska, New Mexico, Oklahoma, South Dakota, Texas, and Wyoming supplies irrigation water for agricultural production. The HPA underlies around $450,658 \mathrm{~km}^{2}$ $\left(174,000 \mathrm{mi}^{2}\right)$ of which the Ogallala aquifer is the principal geologic formation underlying $347,059 \mathrm{~km}^{2}\left(134,000 \mathrm{mi}^{2}\right)$ (Gutentag et al. 1984). The Ogallala aquifer is primarily a water table (unconfined) aquifer with saturated thickness ranging from $0 \mathrm{~m}$ to about $366 \mathrm{~m}$ (McGuire 2017). Average annual precipitation ranges from $400 \mathrm{~mm}$ in the west to $800 \mathrm{~mm}$ in the east of the Ogallala aquifer region (OAR), while mean annual pan evaporation ranges from $1500 \mathrm{~mm}$ in the north to $2700 \mathrm{~mm}$ in the south of the OAR (Zhang et al. 2019).

Agriculture in the OAR is heavily dependent on irrigation with almost $88 \%$ of water withdrawal from the Ogallala aquifer used for crop production (Ajaz et al. 2020). Recent droughts have only exacerbated declines in groundwater (Zhang et al. 2019). Water pumped from the aquifer is primarily applied through center pivot sprinkler systems to irrigate major crops, such as alfalfa (Medicago sativa), maize (Zea mays), cotton (Gossypium hirsutum), soybean (Glycine max), winter wheat (Triticum aestivum), and sorghum (Sorghum bicolor) (Ajaz et al. 2020). Area-weighted state-wide

Allan A. Andales

Allan.Andales@colostate.edu

1 Department of Soil and Crop Sciences, Colorado State University, Fort Collins, CO 80523, USA

2 Department of Biological Systems Engineering, University of Nebraska-Lincoln, Lincoln, NE 68583, USA

3 Department of Civil and Environmental Engineering, Colorado State University, Fort Collins, CO 80523, USA average water level changes in the Ogallala aquifer from predevelopment (1950's) to 2015 ranged from $-12.5 \mathrm{~m}$ (decline) in Texas to $+0.2 \mathrm{~m}$ (increase) in South Dakota, with an area-weighted average decline of $-4.8 \mathrm{~m}$ across the entire aquifer (McGuire 2017). However, local water level changes based on 3164 individual wells exhibited a larger range, with extremes of $+25.6 \mathrm{~m}$ rise in Nebraska to $-71.3 \mathrm{~m}$ decline in Texas during the same period (McGuire 2017).

Sustainability of groundwater pumping to support irrigated agriculture varies across the OAR. Greater saturated thickness and recharge in the northern part of the aquifer (Nebraska and South Dakota) could feasibly sustain pumping while lower recharge and greater evaporative demand in the southern (Texas and New Mexico) and west-central (Colorado, Kansas, and Oklahoma) parts of the OAR make long-term pumping less sustainable (Deines et al. 2020). Although widely varying groundwater policies, governance structures, socio-economic conditions, and climate change impacts exist across the OAR (Gowda et al. 2019), improved irrigation management at the farm level can have a significant impact in conserving groundwater in the OAR (Ajaz et al. 2020). This special issue of Irrigation Science highlights interdisciplinary approaches to improving irrigation management in the OAR through in-field management, deployment of various technologies, and strategic economic or modeling analyses.

\section{Special issue contributions}

The papers in this special issue report results of collaborative research primarily supported by the United States Department of Agriculture (USDA)-National Institute of Food and Agriculture Ogallala Water Coordinated Agriculture Project (CAP) that bring together researchers from more than ten institutions across six States in the OAR (https://ogallalawa 
ter.org/). The nine papers cover a broad range of irrigation management topics under two main categories as follows.

\section{In-field management}

Irrigation management decisions are implemented at the field level and can directly impact water use efficiency and the volume of groundwater pumping. Five papers in this special issue consider various field management strategies and technology levels, and give recommendations for their use or effectiveness. Bordovsky (2020) studied the effects of preplant and early-season irrigations on cotton in the Texas High Plains using subsurface drip irrigation (SDI). CostaFilho et al. (2020) developed a procedure to calculate a crop water stress index (CWSI) based on sensible heat flux estimated using a within canopy or aerodynamic temperature approach, and related CWSI to a soil water stress (deficit) index (SWSI). Lo et al. (2020) monitored changes in soil water and maize canopy temperatures under varying levels of water and nitrogen applications, and introduced the concept of a combined stress coefficient that considers both variables. Schneekloth et al. (2020) evaluated the effects of tillage and residue management on maize grain yield, water infiltration, evapotranspiration, and soil physical attributes under limited irrigation in a semi-arid climate. MitchellMcCallister et al. (2020) performed a meta-analysis of 351 studies from 17 published articles to determine the impact of irrigation system and management operations on water use efficiency (WUE) in the Texas High Plains. They found that the impact of irrigation system on WUE was directly correlated with the efficiency of the irrigation system.

\section{Strategic economic or modeling analyses}

Strategic or long-term irrigation management decisions are best made by considering economic and production impacts of various management strategies. Four papers in this special issue used strategic economic or crop modeling analyses to make irrigation management recommendations. Crouch et al. (2020) conducted a regional analysis in the Texas Panhandle (northern most counties) to project potential water savings and implementation costs of various water management strategies for the years 2020-2070. Reynolds et al. (2020) examined the economic feasibility of converting an existing center pivot irrigation system to a mobile drip irrigation (MDI) application system, which is a technology that has received recent attention in the central Ogallala region. Rad et al. (2020) used crop yield simulations and corresponding downside risk (standard deviation of profits that are below the average profit) to estimate impacts of well capacity, crop choice, soil type, and projected climate change on profit, and demonstrated how downside risk could influence the choice of crop to plant. Masasi et al. (2020) calibrated and tested the AquaCrop model for cotton at two sites in Oklahoma and Texas, and applied the model to investigate the effect of variable irrigation capacity on cotton yields during a 33-year period (1981-2013).

In line with Irrigation Science's special emphasis on multi-disciplinary studies dealing with the challenges of maintaining the long-term productivity of irrigated lands, this special issue presents a broad range of in-field and strategic analyses approaches to improving irrigation management in the Ogallala Aquifer region of the U.S.A.

Acknowledgements The authors appreciate the support of Amy Kremen in coordinating paper submissions from the Ogallala Water CAP project team. This special issue is based on work supported by the National Institute of Food and Agriculture, U.S. Department of Agriculture, under award number 2016-68007-25066, "Sustaining agriculture through adaptive management to preserve the Ogallala aquifer under a changing climate."

\section{References}

Ajaz A, Datta S, Stoodley S (2020) High plains aquifer-state of affairs of irrigated agriculture and role of irrigation in the sustainability paradigm. Sustainability 12:3714. https://doi.org/10.3390/su120 93714

Bordovsky J (2020) Preplant and early-season cotton irrigation timing with deficit amounts using subsurface drip (SDI) systems in the Texas High Plains. Irrig Sci. https://doi.org/10.1007/s0027 1-019-00661-3

Costa-Filho E, Chávez JL, Comas L (2020) Determining maize water stress through a remote sensing-based surface energy balance approach. Irrig Sci. https://doi.org/10.1007/s00271-020-00668-1

Crouch M, Guerrero B, Amosson S, Marek T, Almas L (2020) Analyzing potential water conservation strategies in the Texas Panhandle. Irrig Sci. https://doi.org/10.1007/s00271-020-00691-2

Deines JM, Schipanski ME, Golden B, Zipper SC, Nozari S, Rottler C, Guerrero B, Sharda V (2020) Transitions from irrigated to dryland agriculture in the Ogallala aquifer: land use suitability and regional economic impacts. Agric Water Manag 233:106061. https://doi.org/10.1016/j.agwat.2020.106061

Gowda P, Bailey R, Kisekka I, Lin X, Uddameri V (2019) Featured series introduction: optimizing Ogallala aquifer water use to sustain food systems. J Am Water ResourAssoc 55(1):3-5. https:// doi.org/10.1111/1752-1688.12719

Gutentag, E.D., Heimes, F.J., Krothe, N.C., Luckey, R.R., and Weeks, J.B. (1984) Geohydrology of the High Plains Aquifer in parts of Colorado, Kansas, Nebraska, New Mexico, Oklahoma, South Dakota, Texas, and Wyoming. U.S. Geological Survey Professional Paper 1400-B. U.S. Geological Survey, Alexandria, Virginia. https://doi.org/10.3133/pp1400B

Lo TH, Rudnick DR, DeJonge KC, Bai G, Nakabuye HN, Katimbo A, Ge Y, Franz TE, Qiao X, Heeren DM (2020) Differences in soil water changes and canopy temperature under varying water $X$ nitrogen sufficiency for maize. Irrig Sci. https://doi.org/10.1007/ s00271-020-00683-2

Masasi B, Taghvaeian S, Gowda PH, Marek G, Boman R (2020) Validation and application of AquaCrop for irrigated cotton in the Southern Great Plains of US. Irrig Sci. https://doi.org/10.1007/ s00271-020-00665-4

McGuire, V.L. (2017) Water-level and recoverable water in storage changes, High Plains aquifer, predevelopment to 2015 and 
2013-15: U.S. Geological Survey Scientific Investigations Report 2017-5040, 14. https://doi.org/10.3133/sir20175040.

Mitchell-McCallister D, Cano A, West C (2020) Meta-analysis of crop water use efficiency by irrigation system in the Texas High Plains. Irrig Sci. https://doi.org/10.1007/s00271-020-00696-x

Rad MR, Araya A, Zambreski ZT (2020) Downside Risk of Aquifer Depletion. Irrig Sci. https://doi.org/10.1007/s00271-020-00688-x

Reynolds S, Guerrero B, Golden B, Amosson S, Marek T, Bell JM (2020) Economic feasibility of conversion to mobile drip irrigation in the Central Ogallala region. Irrig Sci. https://doi. org/10.1007/s00271-020-00667-2

Schneekloth J, Calderon F, Nielsen DC, Fonte SJ (2020) Tillage and residue management effects on irrigated maize performance and water cycling in a semiarid cropping system of Eastern Colorado. Irrig Sci. https://doi.org/10.1007/s00271-020-00702-2

Zhang Y, Lin X, Gowda P, Brown D, Zambreski Z, Kutikoff S (2019) Recent Ogallala aquifer region drought conditions as observed by terrestrial water storage anomalies from GRACE. J Am Water ResourAssoc 55(6):1370-1381. https://doi. org/10.1111/1752-1688.12798

Publisher's Note Springer Nature remains neutral with regard to jurisdictional claims in published maps and institutional affiliations. 